\title{
Bioefficacy evaluation and phytotoxicity studies on fungicide Taqat 75\% WP (Captan 70\% + Hexaconazole 5\%) against early blight and powdery mildew diseases in tomato crop
}

\author{
Rishu Sharma* \\ Department of Plant Pathology, Faculty of Agriculture, Bidhan Chandra Krishi \\ Vishwavidyalaya, Mohanpur, Distt.- Nadia \\ *Corresponding author
}

Ke y w o r d s
Tomato, Powdery
mildew, early
blight, Plant
diseases

\section{A B S T R A C T}

Tomato crop is attacked by several pathogens during its cropping season. The present study was undertaken to mitigate the disease incidence using Taqat 75\% WP during the year 2016-17 and 2017-18. Assessment of the disease severity was done by standard scoring methods and expressed as Per cent Disease Index (PDI). For phytotoxicity of Taqat $75 \% \mathrm{WP}$ at X dose $750 \mathrm{~g} / \mathrm{ha}, 2 \mathrm{X}$ dose $1500 \mathrm{~g} / \mathrm{ha}$ and $4 \mathrm{X}$ doses $3000 \mathrm{~g} / \mathrm{ha}$ along with the standard check treatments. The observations on leaf injury, wilting, vein clearing, necrosis, epinasty \& hyponasty were recorded on ten randomly selected plants before spray at 3,7 and 15 days after $1^{\text {st }}$ spray. The observations were recorded on early blight and powdery mildew before application and at different intervals after the application of Taqat $75 \%$ WP.Thus, our studies revealed that the per cent disease index of Taqat 75\% WP (Captan $70 \%+$ Hexaconazole 5\%) @ $750 \mathrm{~g} / \mathrm{ha}$ is highly effective in controlling Early blight and powdery mildew diseases of tomato and increasing tomato fruit yield without causing any phytotoxicity to the crop.

\section{Introduction}

Tomato (Lycopersicon esculentum Mill.) belongs to the family Solanaceae and it is considered one of the world's most popular vegetables (Pritesh et al., 2011). It is the most important tropical vegetable crop widely used throughout the world (Hadian et al., 2011). It is a high-value horticultural crop for the local market and an important dietary component, contributing to improved nutrition and livelihood for both rural and urban population (Waiganjo et al., 2006).

The fruits are used fresh in salads or cooked as a vegetable, in processed form as tomato paste (puree), tomato sauce, ketchup, juice and can also be dried. They are rich in 
vitamins $\mathrm{A}$ and $\mathrm{C}$ and are gaining importance because it contains lycopene, a food component known to reduce the incidence of prostate cancer, heart and age related diseases (AVRDC, 2003). Tomato is a indispensable part of staple food diets across the world.

But, it is attacked by several plant pathogens causing viz. Early blight (Alternaria solani), powdery mildew (Leveillula taurica), leaf curl, an insect vector (white fly, Bemisia tabaci) transmitted virus disease, is another major problem in tomato cultivation. In the present Study, disease incidence and phytotoxicity studies using Taqat $75 \%$ WP during the year 2016-17 and 2017 were carried.

Assessment of the disease severity was done by standard scoring methods, and expressed as Per cent Disease Index (PDI). For phytotoxicity of Taqat $75 \% \mathrm{WP}$ at $\mathrm{X}$ dose $750 \mathrm{~g} / \mathrm{ha}, 2 \mathrm{X}$ dose $1500 \mathrm{~g} / \mathrm{ha}$ and $4 \mathrm{X}$ doses $3000 \mathrm{~g} / \mathrm{ha}$ along with the standard check treatments. The observations on leaf injury, wilting, vein clearing, necrosis, epinasty \& hyponasty were recorded on ten randomly selected plants before spray, 3, 7 and 15 days after $1^{\text {st }}$ spray.

\section{Materials and Methods}

A local tomato variety Patharkuchi was grown during Rabi, 2016-17 and 2017-18 and the experimental layout was made with nine treatments and three replications for the bioefficacy studies with a spacing of $60 \times 40$ $\mathrm{cm}^{2}$ and six treatments for the phytotoxicity studies.

All the agronomical practices were followed as per the standard package of practices recommendations. Assessment of the disease severity was done by scoring methods as given below and expressed as Per cent Disease Index (PDI).

\section{Bio-efficacy of taqat}

On appearance of the diseases, fungicides were sprayed with knapsack sprayer fitted with hollow cone nozzle. The per cent disease incidence on leaves and fruits were recorded before spray initiation and at different intervals after each spray on randomly selected 25 leaves of five plants. Assessment of the disease severity was done by scoring methods as given below and expressed as Per cent Disease Index (PDI) (Table 1\& 2).

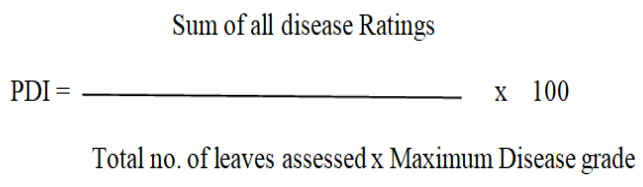

\section{Phytotoxicity of taqat $75 \%$ WP on tomato}

For phytotoxicity of Taqat $75 \% \mathrm{WP}$ at $\mathrm{X}$ dose $750 \mathrm{~g} / \mathrm{ha}, 2 \mathrm{X}$ dose $1500 \mathrm{~g} / \mathrm{ha}$ and $4 \mathrm{X}$ doses $3000 \mathrm{~g} / \mathrm{ha}$ along with the standard check treatments. The observations on leaf injury, wilting, vein clearing, necrosis, epinasty \& hyponasty were recorded on ten randomly selected plants before spray, 3, 7 and 15 days after $1^{\text {st }}$ spray. The level of phytotoxicity was estimated by visual assessment on below mentioned scale of $0-10$.

The observations on diseases of tomato viz., early blight, powdery mildew before application and at different intervals after the application of Taqat $75 \% \mathrm{WP}$, its individual products and the standard check fungicides, Captan 50\%WP @ $2500 \mathrm{~g} / \mathrm{ha}$ and Mancozeb 75\%WP @ $1500 \mathrm{~g} / \mathrm{ha}$ along with the untreated control treatment were recorded.

For phytotoxicity of Taqat $75 \% \mathrm{WP}$ at the recommended dose, $750 \mathrm{~g} / \mathrm{ha}$ and double the recommended dose, $1500 \mathrm{~g} / \mathrm{ha}$ and four times the recommended dose, $3000 \mathrm{~g} / \mathrm{ha}$ along with the standard check treatments. All the field experimental conditions were kept constant. 


\section{Experimental results}

The observations on major diseases of tomato viz., early blight and powdery mildew before application and at different intervals after the application of Taqat $75 \% \mathrm{WP}$, its individual products and the standard check fungicides, Captan 50\%WP @ $2500 \mathrm{~g} / \mathrm{ha}$ and Mancozeb $75 \% W P @ 1500 \mathrm{~g} / \mathrm{ha}$ along with the untreated control treatment were recorded. The per cent disease index worked out was analyzed statistically. The data on early blight and powdery mildew were presented in tables $1,2,3 \& 4$ respectively and the results are discussed below.

\section{Early blight disease of tomato}

During the year 2016-17, the Per cent Disease Index (PDI) for early blight was between 8.15 $\& 9.78$ at the time of spray initiation which indicates the uniform disease incidence. After the application of fungicides, all the fungicides exhibited significantly superior efficacy against early blight disease while during the year 2017-18, The Per cent Disease Index (PDI) for early blight was between 6.67 $\& 7.26$ at the time of spray initiation which indicates the uniform disease incidence. After the application of fungicides, all the treatments exhibited significantly superior efficacy against early blight disease.

The mean PDI after two applications during 2016-17 was minimum in the treatment, Taqat 75\%WP@750g/ha recording 11.52, which was followed by Taqat $75 \% \mathrm{WP} @ 500 \mathrm{~g} / \mathrm{ha}$ (14.00 PDI), Hexaconazole 5\%EC @ $750 \mathrm{ml} / \mathrm{ha}$ (14.74 PDI), and Hexaconazole 5\%EC@ $@ 500 \mathrm{ml} / \mathrm{ha}$ (16.11 PDI). The standard check treatments, Captan 50\%WP @ 2500g/ha recorded 19.26 PDI and Mancozeb 75\%WP @ 1500g/ha recorded 20.33 PDI. Maximum PDI of 58.19 was recorded in untreated control (Table 4). The mean PDI after two applications during 2017-18 was minimum in the treatment, Taqat 75\%WP @ $750 \mathrm{~g} /$ ha recording 8.96, which was followed by Taqat 75\%WP @ 500g/ha (12.04 PDI) and Hexaconazole 5\%EC @ 750ml/ha (12.41 PDI), Hexaconazole 5\%EC @ 500ml/ha (14.30 PDI). The standard check treatments, Captan 50\%WP @ 2500g/ha recorded 15.81 PDI and Mancozeb 75\%WP @ 1500g/ha recorded 16.70 PDI. Maximum PDI of 49.37 was recorded in untreated control (Table 5).

The Per cent Disease Index (PDI) for Powdery mildew was between $6.22 \& 8.44$ at the time of spray initiation which indicates the uniform disease incidence. After the application of fungicides, all the treatments exhibited significantly superior efficacy against powdery mildew disease. The Per cent Disease Index (PDI) for Powdery mildew was between $7.11 \& 8.44$ during 2017-18 at the time of spray initiation which indicates the uniform disease incidence (Table $6 \& 7$ )

The mean PDI after two applications was minimum in the treatment (T2), Taqat 75\%WP @750g/ha recording 7.70, Which was followed by (T1) Taqat 75\%WP @ 500g/ha (10.44 PDI), Hexaconazole 5\%EC @ $750 \mathrm{ml} / \mathrm{ha}$ (10.52 PDI) and Hexaconazole 5\%EC@ $@ 500 \mathrm{ml} / \mathrm{ha}$ (12.37 PDI). The standard checks treatments, Captan 50\%WP @ 2500g/ha recorded 15.41 PDI and Mancozeb 75\%WP @ 1500g/ha recorded 14.74 PDI. Untreated control recorded the maximum of 38.81 PDI. (Table 6). The mean PDI during 2017-18 after two applications was minimum in the treatment, Taqat 75\%WP @ 750g/ha recording 8.15 . which was followed by Taqat 75\%WP @ 500g/ha (10.37 PDI), Hexaconazole 5\%EC @ 750ml/ha (10.67 PDI) and Hexaconazole 5\%EC @ 500ml/ha (12.59 PDI). The standard checks treatments, Captan 50\%WP @ 2500g/ha recorded 13.63 PDI and Mancozeb 75\%WP @ 1500g/ha recorded 13.93 PDI. Untreated control recorded the maximum of 41.48 PDI. (Table 7). 


\section{Effect on yield}

All the fungicidal treatments showed the impact on the increase in the fruit yield. Maximum fruit yield of 30.32 tones/ha was recorded in Taqat 75\%WP @ 750g/ha. Which was followed by its lower dose of $500 \mathrm{~g} / \mathrm{ha}$ (28.56 tones/ha), Hexaconazole 5\%EC @ $750 \mathrm{ml} / \mathrm{ha}$ recorded 28.20 tones/ha, Captan 50\%WP @ 2500g/ha recorded 27.72 tones/ha, Captan 50\%WP @ 1050g/ha recorded 27.53tones/ha, Hexaconazole 5\%EC @ $500 \mathrm{ml} / \mathrm{ha}$ recorded 25.61 tones $/ \mathrm{ha}$ and minimum fruit yield of 22.98 tones was in untreated control (Fig. 1\&2). All the fungicidal treatments showed the impact on the increase in the fruit yield. Maximum fruit yield of 28.76 tones/ha was recorded in Taqat
75\%WP @ 750g/ha. Which was followed by its lower dose of $500 \mathrm{~g} / \mathrm{ha}(27.73$ tones $/ \mathrm{ha})$, Hexaconazole 5\%EC @ 750ml/ha recorded 27.26 tones/ha, Captan 50\%WP @ 2500g/ha recorded 26.79 tones/ha, Captan 50\%WP @ $1050 \mathrm{~g} / \mathrm{ha}$ recorded 26.61 tones/ha and Minimum fruit yield of 22.56 tones was recorded in untreated control (Fig. 1\&2).

\section{Phytotoxicity}

The results on the phytotoxicity showed that, treatments with Taqat 75\%WP @ 750g/ha, $1500 \mathrm{~g} / \mathrm{ha} \& 3000 \mathrm{~g} / \mathrm{ha}$ did not show any phytotoxic symptoms at any of the observation intervals during the 2016-17 and 2017-18. This shows that, Taqat 75\%WP is non phytotoxic to the tomato crop.

Table.1 Disease scoring scale for early blight

\begin{tabular}{|c|l|}
\hline Score & \multicolumn{1}{|c|}{ Symptoms } \\
\hline 0 & Not seen on field \\
\hline 1 & $\begin{array}{l}\text { Only a few plants affected here and there, up to } 1 \text { or } 2 \text { spots per plot. Up to } 10 \text { spots per } \\
\text { plant. }\end{array}$ \\
\hline 3 & About 50 spots per plant, or up to 1 leaf let in 10 attacked \\
\hline 5 & $\begin{array}{l}\text { Nearly every leaflet with lesions, plants still retaining normal form; field may smell of } \\
\text { blight but looks green, although every plant is affected }\end{array}$ \\
\hline 7 & $\begin{array}{l}\text { Every plant affected and about } 1 / 2 \text { of leaf area destroyed by blight; field looks green } \\
\text { flecked with brown }\end{array}$ \\
\hline 9 & $\begin{array}{l}\text { About } 3 / 4 \text { of leaf area destroyed by blight; field looks either predominantly brown or } \\
\text { green. In some varieties the youngest leaves escape infection. Only few leaves left green } \\
\text { but stem remain green. All leaves dead, stems dead or dying }\end{array}$ \\
\hline
\end{tabular}

Table.2 Disease scoring scale for Powdery mildew

\begin{tabular}{|c|l|}
\hline Score & Symptoms \\
\hline 0 & No symptoms of powdery mildew \\
\hline 1 & Small scattered powdery mildew specks covering 1 per cent or less leaf area \\
\hline 3 & Small powdery lesions covering 1-10 per cent of leaf area \\
\hline 5 & Powdery lesions enlarged covering 11-25 per cent of leaf area \\
\hline 7 & Powdery lesions coalesce to form big patches covering 26- 50 per cent of leaf area \\
\hline 9 & Big powdery patches covering 51 per cent or more of leaf area and defoliation occur \\
\hline
\end{tabular}


Table.3 Scale for phytotoxicity

\begin{tabular}{|c|c|}
\hline Score & Phytotoxicity (\%) \\
\hline $\mathbf{0}$ & No phytotoxicity \\
\hline $\mathbf{1}$ & $1-10$ \\
\hline $\mathbf{2}$ & $11-20$ \\
\hline $\mathbf{3}$ & $21-30$ \\
\hline $\mathbf{4}$ & $31-40$ \\
\hline $\mathbf{5}$ & $41-50$ \\
\hline $\mathbf{6}$ & $51-60$ \\
\hline $\mathbf{7}$ & $61-70$ \\
\hline $\mathbf{8}$ & $71-80$ \\
\hline $\mathbf{9}$ & $81-90$ \\
\hline $\mathbf{1 0}$ & $91-100$ \\
\hline
\end{tabular}

Table.4 Effect of Taqat 75\% WP against early blight in Tomato during Rabi, 2016-17

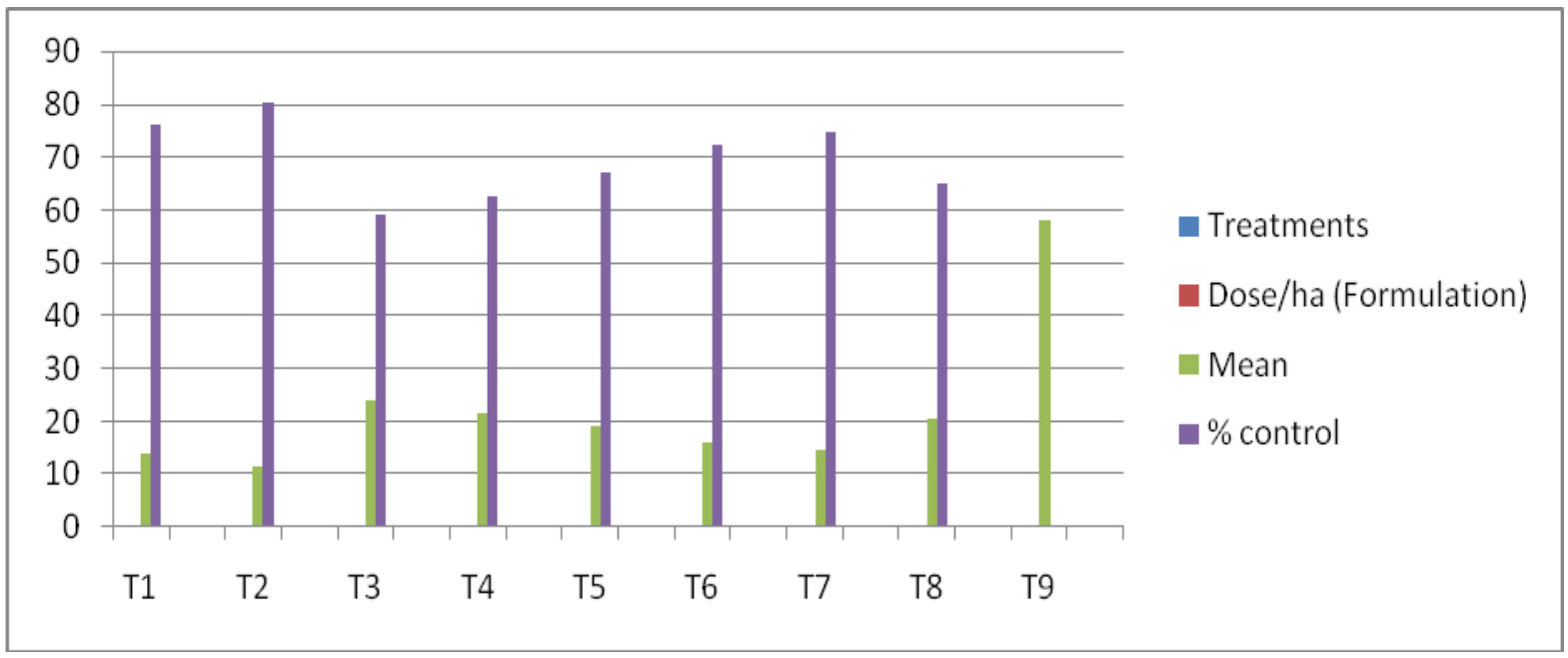

Table.5 Effect of Taqat 75\% WP against early blight in Tomato during Rabi, 2017-18

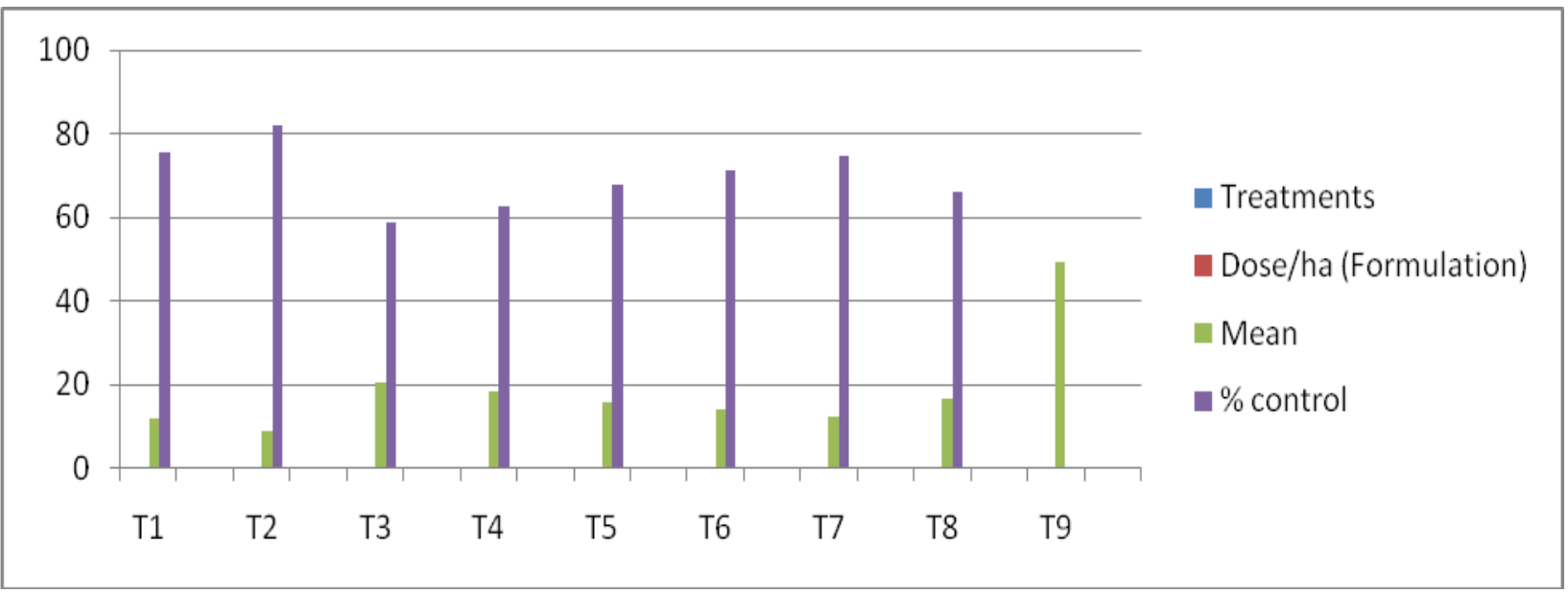


Table.6 Effect of Taqat 75\% WP against powdery mildew disease in Tomato during Rabi, 2016-17

\begin{tabular}{|c|c|c|c|c|c|c|c|}
\hline \multirow[t]{2}{*}{ Tr. No } & \multirow[t]{2}{*}{ Treatments } & \multirow{2}{*}{$\begin{array}{c}\text { Dose/ha } \\
\text { (Formulation) }\end{array}$} & \multicolumn{3}{|c|}{ Per cent Disease Index (PDI) } & \multirow[t]{2}{*}{ Mean } & \multirow[t]{2}{*}{$\%$ Control } \\
\hline & & & $\begin{array}{c}\text { Pre- } \\
\text { treatment }\end{array}$ & $\begin{array}{l}10 \text { Days After } \\
1^{\text {st }} \text { spray }\end{array}$ & $\begin{array}{c}10 \text { Days After } \\
2^{\text {nd }} \text { spray }\end{array}$ & & \\
\hline T1 & Taqat $75 \% \mathrm{WP}$ & $500 \mathrm{~g}$ & $\begin{array}{c}6.96 \\
(15.28)\end{array}$ & $\begin{array}{c}9.04 \\
(17.46)\end{array}$ & $\begin{array}{l}11.85 \\
(20.07)\end{array}$ & 10.44 & 73.09 \\
\hline T2 & Taqat $75 \% \mathrm{WP}$ & $750 \mathrm{~g}$ & $\begin{array}{c}6.22 \\
(14.39)\end{array}$ & $\begin{array}{c}7.41 \\
(15.73)\end{array}$ & $\begin{array}{c}8.00 \\
(16.41)\end{array}$ & 7.70 & 80.15 \\
\hline T3 & Captan 50\%WP & $700 \mathrm{~g}$ & $\begin{array}{c}7.26 \\
(15.62)\end{array}$ & $\begin{array}{l}17.78 \\
(24.91)\end{array}$ & $\begin{array}{c}19.56 \\
(26.23)\end{array}$ & 18.67 & 51.91 \\
\hline T4 & Captan 50\%WP & $1050 \mathrm{~g}$ & $\begin{array}{c}6.81 \\
(15.08)\end{array}$ & $\begin{array}{c}15.56 \\
(23.22)\end{array}$ & $\begin{array}{l}17.78 \\
(24.92)\end{array}$ & 16.67 & 57.06 \\
\hline T5 & Captan 50\%WP & $2500 \mathrm{~g}$ & $\begin{array}{c}7.11 \\
(15.44)\end{array}$ & $\begin{array}{c}14.67 \\
(22.51)\end{array}$ & $\begin{array}{l}16.15 \\
(23.68)\end{array}$ & 15.41 & 60.31 \\
\hline T6 & $\begin{array}{l}\text { Hexaconazole } \\
5 \% \text { EC }\end{array}$ & $500 \mathrm{ml}$ & $\begin{array}{c}6.96 \\
(15.23)\end{array}$ & $\begin{array}{c}10.96 \\
(19.21)\end{array}$ & $\begin{array}{l}13.78 \\
(21.77)\end{array}$ & 12.37 & 68.13 \\
\hline T7 & $\begin{array}{l}\text { Hexaconazole } \\
5 \% \text { EC }\end{array}$ & $750 \mathrm{ml}$ & $\begin{array}{c}6.67 \\
(14.94)\end{array}$ & $\begin{array}{c}9.19 \\
(17.63)\end{array}$ & $\begin{array}{l}11.85 \\
(20.09)\end{array}$ & 10.52 & 72.90 \\
\hline T8 & $\begin{array}{l}\text { Mancozeb 75\% } \\
\text { WP }\end{array}$ & $1500 \mathrm{~g}$ & $\begin{array}{c}7.26 \\
(15.58)\end{array}$ & $\begin{array}{c}13.19 \\
(21.23)\end{array}$ & $\begin{array}{c}16.30 \\
(23.72)\end{array}$ & 14.74 & 62.02 \\
\hline T9 & $\begin{array}{l}\text { Untreated } \\
\text { control }\end{array}$ & - & $\begin{array}{c}8.44 \\
(16.89)\end{array}$ & $\begin{array}{c}33.63 \\
(35.42)\end{array}$ & $\begin{array}{c}44.00 \\
(41.49)\end{array}$ & 38.81 & \\
\hline & S.Em \pm & & 0.63 & 0.92 & 1.32 & & \\
\hline & CD at $5 \%$ & & 1.90 & 2.76 & 3.95 & & \\
\hline
\end{tabular}

Table.7 Effect of Taqat 75\% WP against powdery mildew in Tomato during Rabi, 2017-18

\begin{tabular}{|c|c|c|c|c|c|c|c|}
\hline \multirow{2}{*}{$\begin{array}{l}\text { Tr. } \\
\text { No }\end{array}$} & \multirow[t]{2}{*}{ Treatments } & \multirow{2}{*}{$\begin{array}{c}\text { Dose/ha } \\
\text { (Formulation) }\end{array}$} & \multicolumn{3}{|c|}{ Per cent Disease Index (PDI) } & \multirow[t]{2}{*}{ Mean } & \multirow[t]{2}{*}{$\%$ control } \\
\hline & & & Pre- treatment & $\begin{array}{l}10 \text { Days After } \\
1^{\text {st }} \text { spray }\end{array}$ & $\begin{array}{l}10 \text { Days After } \\
2^{\text {nd }} \text { spray }\end{array}$ & & \\
\hline T1 & Taqat $75 \% \mathrm{WP}$ & $500 \mathrm{~g}$ & $\begin{array}{c}7.85 \\
(16.25)\end{array}$ & $\begin{array}{c}9.78 \\
(18.21)\end{array}$ & $\begin{array}{c}10.96 \\
(19.32)\end{array}$ & 10.37 & 75.00 \\
\hline T2 & Taqat $75 \% \mathrm{WP}$ & $750 \mathrm{~g}$ & $\begin{array}{c}7.56 \\
(15.95)\end{array}$ & $\begin{array}{c}8.00 \\
(16.41)\end{array}$ & $\begin{array}{c}8.30 \\
(16.72)\end{array}$ & 8.15 & 80.36 \\
\hline T3 & Captan 50\%WP & $700 \mathrm{~g}$ & $\begin{array}{c}7.85 \\
(16.26)\end{array}$ & $\begin{array}{c}16.89 \\
(24.22)\end{array}$ & $\begin{array}{c}18.67 \\
(25.57)\end{array}$ & 17.78 & 57.14 \\
\hline T4 & Captan 50\%WP & $1050 \mathrm{~g}$ & $\begin{array}{c}7.56 \\
(15.95)\end{array}$ & $\begin{array}{l}14.96 \\
(22.74)\end{array}$ & $\begin{array}{c}16.59 \\
(24.02)\end{array}$ & 15.78 & 61.96 \\
\hline T5 & Captan 50\%WP & $2500 \mathrm{~g}$ & $\begin{array}{c}7.11 \\
(15.44)\end{array}$ & $\begin{array}{c}12.59 \\
(20.77)\end{array}$ & $\begin{array}{c}14.67 \\
(22.50)\end{array}$ & 13.63 & 67.14 \\
\hline T6 & $\begin{array}{l}\text { Hexaconazole } \\
5 \% \text { EC }\end{array}$ & $500 \mathrm{ml}$ & $\begin{array}{c}8.00 \\
(16.41)\end{array}$ & $\begin{array}{c}11.41 \\
(19.62)\end{array}$ & $\begin{array}{l}13.78 \\
(21.77)\end{array}$ & 12.59 & 69.64 \\
\hline T7 & $\begin{array}{l}\text { Hexaconazole } \\
5 \% \text { EC }\end{array}$ & $750 \mathrm{ml}$ & $\begin{array}{c}7.11 \\
(15.46)\end{array}$ & $\begin{array}{c}9.33 \\
(17.78)\end{array}$ & $\begin{array}{l}12.00 \\
(20.23)\end{array}$ & 10.67 & 74.29 \\
\hline T8 & $\begin{array}{l}\text { Mancozeb } 75 \% \\
\text { WP }\end{array}$ & $1500 \mathrm{~g}$ & $\begin{array}{c}8.44 \\
(16.85)\end{array}$ & $\begin{array}{l}13.33 \\
(21.40)\end{array}$ & $\begin{array}{c}14.52 \\
(22.39)\end{array}$ & 13.93 & 66.43 \\
\hline T9 & $\begin{array}{l}\text { Untreated } \\
\text { control }\end{array}$ & - & $\begin{array}{c}8.44 \\
(16.89)\end{array}$ & $\begin{array}{c}37.78 \\
(37.91)\end{array}$ & $\begin{array}{c}45.19 \\
(42.21)\end{array}$ & 41.48 & \\
\hline & S.Em \pm & & 0.41 & 0.76 & 0.72 & & \\
\hline & CD at $5 \%$ & & 1.23 & 2.28 & 2.17 & & \\
\hline
\end{tabular}




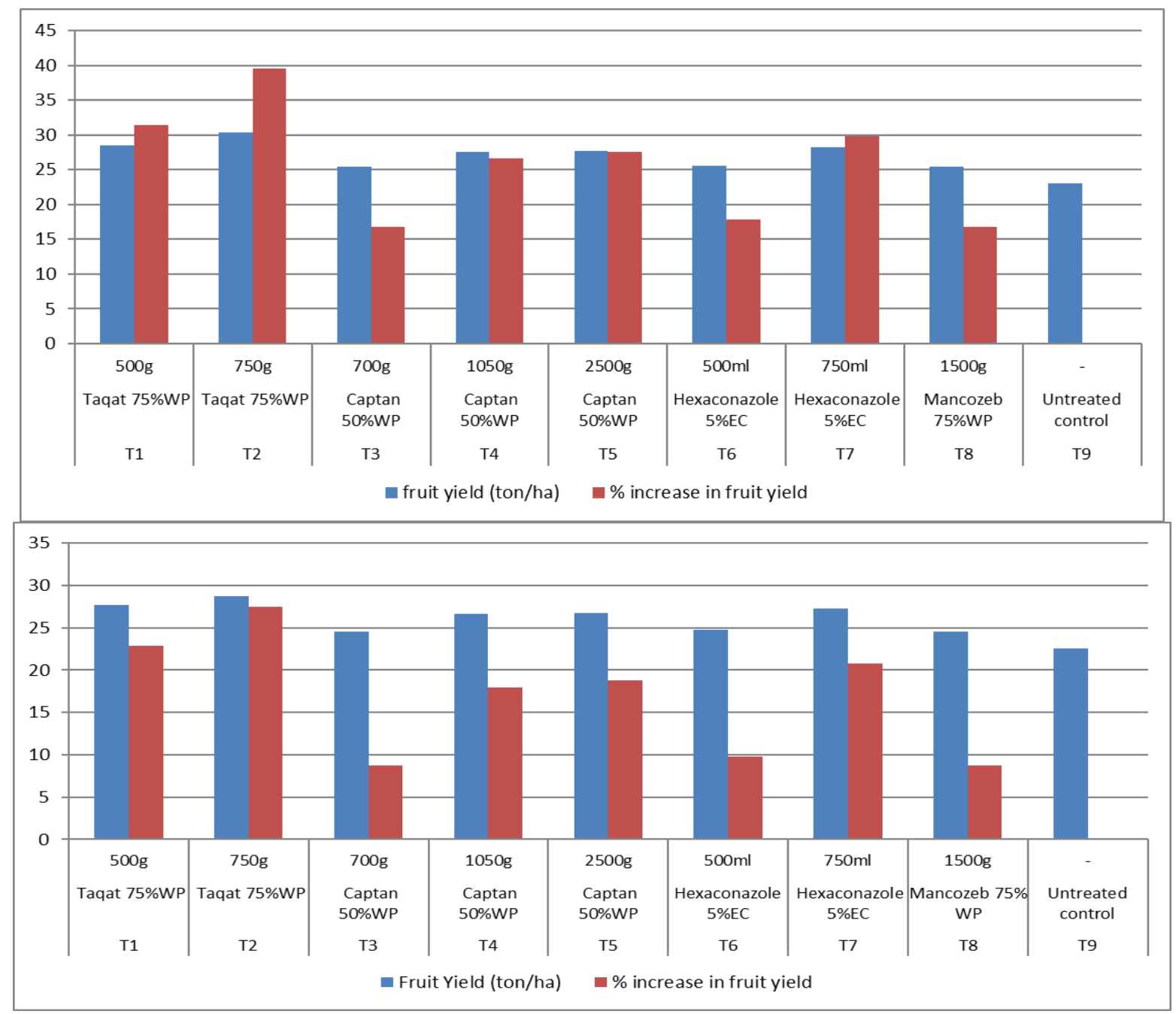

Fig.1 Effect of Taqat 75\%WP on fruit yield of tomato during Rabi, 2016-17 and 2017-18

Based on experimental results obtained during both trials during the year 2016-17 and 201718 it can be concluded that Taqat $75 \%$ WP (Captan 70\% + Hexaconazole 5\%) @ 750 $\mathrm{g} / \mathrm{ha}$ is highly effective in controlling Early blight, powdery mildew diseases of tomato and increasing tomato fruit yield. Also, the application of Taqat $75 \% \mathrm{WP}$ is not causing any phytotoxicity to the crop.

\section{Acknowledgement}

I highly grateful to funding agency Rallis India Pvt. Ltd, Bangalore, India and BCKV for conducting the cropping trials in the university farm.

\section{References}

AVRDC (2003). Asian Vegetable Research and Development Corporation, Progress Report. Variations of anti-oxidants and their activity in tomato. 70-115

Hadian, S., Rahnam, K., Jamali, S. and Escandari, A. 2011. Comparing New Extract with Chemical Control on Fusarium oxysporum I and Meloidogyne incognita complex of tomato. Advances in Environmental Biology. 5(8):2052-2057

Pritesh, P and Subramanian, R.B. (2011). PCR based method for testing Fusarium wilt resistance of Tomato. African Journal of Basic and Applied Sciences. 
$3(5), 222$.

Waiganjo, M.M., Wabule,N.M., Nyongesa,

D., Kibaki, J.M., Onyango, I.,

Webukhulu, S.B. and Muthoka, N.M.
(2006). Tomato production in Kiriyanga District, Kenya. A baseline survey report. KARI/IPM-CRSP Collaborative project.

\section{How to cite this article:}

Rishu Sharma. 2020. Bioefficacy evaluation and phytotoxicity studies on fungicide Taqat 75\%WP (Captan 70\% + Hexaconazole 5\%) against early blight and powdery mildew diseases in tomato crop. Int.J.Curr.Microbiol.App.Sci. 9(03): 3055-3062.

doi: https://doi.org/10.20546/ijcmas.2020.903.350 